\title{
Upaya Guru PPKn dalam Pembinaan Moral Melalui Pendekatan Ibadah Salat Berjamaah di SMAN 2 Sungai Limau
}

Nofrio Chandra, Ideal Putra

Prodi Pendidikan Pancasila dan Kewarganegaraan

Universitas Negeri Padang

E-mail: nofriochandra@gmail.com

\section{ABSTRAK}

Artikel ini bertujuan untuk mendeskripsikan peran guru PPKn dalam menanamkan nilai-nilai moral kepada peserta didik, sehingga pembinaan yang dilakukan oleh guru PPKn dapat berguna jika peserta didik melangkah ke usia remaja dan dewasa. Penelitian ini menggunakan metode kualitatif deskriptif yang dilakukan di SMAN 2 Sungai Limau didasarkan pada purposive sampling melalui beberapa orang yang dianggap dapat memberikan keterangan berdasarkan kriteria yang ditetapkan oleh peneliti. Hasil penelitian menunjukkan bahwa upaya guru PPKn serta keterlibatan elemen lainnya dalam pembinaan moral telah optimal. Hal ini dapat dibuktikan dengan guru PPKn memberikan pengarahan dan menayangkan video tentang pentingnya melaksanakan salat berjamaah disekolah. Kegiatan tersebut diawasi secara ketat oleh tim disiplin sekolah SMAN 2 Sungai Limau. Seharusnya program salat zuhur berjamaah dapat dipertahankan dan lebih ditingkatkan kepada aktivitas lain yang berhubunngan dengan pembinaan moral bagi siswa siswi SMAN 2 Sungai Limau sehingga dapat menjadikan siswa memiliki moral yang baik dan menjadi contoh teladan bagi siswa yang lain. Maka dari itu sekolah membentuk sebuah tim disiplin sekolah yang dikomandoi oleh wakil kesiswaan untuk mengedepankan moral yang baik.

Kata Kunci: pembinaan moral, pembelajaran, PPKn, Sungai Limau

\section{ABSTRACT}

This article aims to describe the role of PPKn teachers in instilling moral values in students, so that coaching conducted by PPKn teachers can be useful if students step into adolescence and adulthood. This research uses descriptive qualitative method conducted at SMAN 2 Sungai Limau based on purposive sampling through several people who are considered to be able to provide information based on criteria established by researchers. The results showed that the PPKn teacher's efforts as well as the involvement of other elements in moral coaching had been optimal. This can be proven by the PPKn teacher giving directions and showing videos about the importance of performing congregational prayers at school. The activity was closely monitored by the Sungai Limau SMAN 2 school discipline team. The midday prayer program can be maintained and further improved to other activities related to moral guidance for students of Sungai Limau SMAN 2 so that students can have good morals 
and set an example for other students. Therefore the school forms a school discipline team that is commanded by student representatives to prioritize good morals.

Keywords : : moral guidance, learning, PPKn, Sungai Limau author.

\section{PENDAHULUAN}

Pendidikan merupakan sebuah proses pemberdayaan, yang diharapkan mampu memberdayakan peserta didik menjadi manusia yang cerdas, berilmu pengetahuan, serta menjadi manusia terdidik. Pemberdayaan siswa misalnya dilakukan melalui proses belajar, proses latihan, proses memperoleh pengalaman atau melalui kegiatan lainya. Pemberdayaan yang dimaksud disini adalah bagaimana institusi pendidikan atau sekolah mampu memberdayakan peserta didik menjadi manusia yang cerdas, berilmu pengetahuan serta menjadi manusia yang terdidik.

Indikator kecerdasan adalah cerdas dalam akademik, cerdas dalam beradaptasi dengan lingkungan, serta cerdas dalam memahami dan menghayati sikap-sikap positif yang berada di tengah masyarakat. Indikator berilmu pengetahuan menurut ahli adalah mampu mengaplikasikan dan menerapkan suatu ilmu yang telah dipahami oleh peserta didik. Indikator menjadi manusia yang terdidik adalah ketika peserta didik memiliki akhlak dan perilaku yang baik. Jadi dapat disimpulkan bahwasanya pendidikan adalah sebuah proses pemberdayaan agar peserta didik memiliki tiga indikator tersebut yaitu cerdas dalam beradaptasi dengan lingkungan, mampu mengaplikasikan dan menerapkan ilmu pengetahuan yang didapat, serta peserta didik memiliki akhlak dan perilaku yang baik.(Uno, 2007:11)

Kajian moral mengkaji secara afektif yaitu menyangkut sikap batin seseorang. Hukum hanya dapat melarang perbuatan-perbuatan manusia secara lahiriah sedangkan dalam konteks moralitas sikap batin sangat dipentingkan. Satu-satunya sanksi di bidang moralitas adalah hari nurani yang tidak tenang karena menuduh seseorang akan perbuatanya yang tidak baik. Hati nurani juga memainkan peranan, baik yang menyangkut perasaan, kehendak, maupun rasio. (Budinigsih, 2013:30). Peran guru PPKn dalam menanamkan nilai-nilai moral kepada peserta didik sehingga apa yang telah disampaikan oleh guru PPKn dalam menanamkan nilai-nilai moral akan masuk ke dalam jiwa peserta didik sehingga pembinaan yang dilakukan oleh guru PPKn dapat berguna jika peserta didik melangkah keusia remaja dan dewasa.

Berdasarkan observasi awal ditemukan beberapa masalah terkait dengan pembinaan moral melalui pendekatan ibadah salat berjamaah yaitu kurangnya kesadaran peserta 
didik dalam melaksanakan ibadah salat zuhur berjamaah, lalainya peserta didk dalam melaksanakan salat zuhur berjamaah, dan ketika suara azan telah berkumandang peserta didik tidak menghiraukan panggilan azan. Guru PPKn dan seluruh stakeholder sekolah harus bekerjasama dalam menanggulangi permasalahan moral yang ada seperti mendekatkan siswa dengan nilai-nilai rohani contohnya dengan melakukan ibadah salat.

\section{Agama Islam menjelaskan} bahwa salat dapat mencegah dari perbuatan keji dan mungkar. Jika siswa melakukan ibadah salat dan melalui ibadah salat, perbuatan keji dan mungkar dapat diatasi. Pentingnya pendidikan moral kepada peserta didik adalah dengan penanaman moral maka akan terbentuk siswa yang berakhlak mulia, dan bertakwa kepada Tuhan Yang Maha Esa serta diharapkan siswa bisa beradaptasi dengan masyarakat melalui pembinaan moral yang dilakukan oleh sekolah.

\section{METODE PENELITIAN}

Jenis penelitian yang digunakan adalah penelitian kualitatif metode deskriptif. Bogdan dan Taylor dalam (Sugiyono, 2003:88) menyatakan bahwa penelitian kualitatif adalah salah satu prosedur penelitian yang menghasilkan data deskriptif berupa ucapan atau tulisan dan perilaku orang-orangyang diamati. Menurut Suryabrata dalam (Sugiyono,2003:75) metode deskripsi bertujuan untuk membuat pecandraan secara sistematis, faktual, dan akurat mengenai fakta-fakta dan sifat-sifat populasi atau daerah tertentu.

Bogdan dan Taylor (1975) dalam Lexy J. Moleong (2013:4), juga menjelaskan metode kualitatif sebagai prosedur penelitian yang menghasilkan data deskriptif berupa kata-kata tertulis atau lisan dari orangorang dan prilaku yang dapat diamati. Penelitian dilakukan di SMAN 2 Sungai Limau Kecamatan Sungai Limau Kabupaten Padang Pariaman. Adapun pertimbangan peneliti memilih lokasi penelitian ini karena sekolah ini terkenal akan identitas dan ciri khas islami serta di sekolah ini juga dilengkapi dengan sarana dan prasarana yang memadai guna meningkatkan siswa dalam beribadah.

Teknik yang digunakan untuk penjamin keabsahan data dalam penelitian ini adalah teknik triangulasi, yaitu melakukan pengecekan data atau kredibilitas data dengan berbagai teknik pengumpulan data dan berbagai sumber datamenggunakan beragam sumber, metode dan teknik. (Sugiyono, 2003: 83). Adapun teknik triangulasi yang digunakan dalam penelitian ini adalah triangulasi sumber dan triangulasi metode. Data dan informasi yang diperoleh disesuaikan dengan aspek-aspek penelitian.

Hal ini dilakukan untuk mempermudah dalam menganalisa data yang selanjutnya data dan informasi akan dideskripsikan dalam bentuk temuan penelitian. Dalam kenyataanya analisis data kualitatif dilakukan selama proses pengumpulan data dari pada setelah selesai pengumpulan data. Adapun teknik analisis atau pengolahan data dikemukakan oleh Miles dan Huberman dalam Sugiyono (2012:338342) dilakukan dengan beberapa tahapan. 
HASIL DAN PEMBAHASAN

Pelaksanaan Pembinaan Moral
Melalui Pendekatan Ibadah Salat
Berjamaah yang dilakukan oleh Guru

a. Memberikan pengarahan kepada siswa tentang moral agama

Selain kedisiplinan bentuk upaya utama yang diberikan guruguru SMAN 2 Sungai Limau ialah keteladanan dalam beribadah. Guruguru dan siswa melaksanakan salat berjamaah di mushola sehingga mereka berupaya untuk memberikan contoh yang baik kepada siswa dan ketika dalam melaksanakan ibadah salat guru selalu membimbing dan mengarahkan siswa berdoa dan berdzikir setiap selesai salat, serta ketika suara azan telah berkumandang di mushola.

Guru mengarahkan seluruh siswa untuk datang ke mushola melaksanakan ibadah salat zuhur berjamaah melalui tim yang telah dibuat oleh kepala sekolah yang dikomandoi oleh wakil kepala sekolah yaitu TDS (Tim Disiplin Sekolah) yang tujuan agar seluruh siswa melaksanakan ibadah salat zuhur berjamaah secara tepat waktu. Sebelum melaksanakan ibadah salat zuhur berjamaah kelas yang telah diamanahkan sebagai pelaksana ibadah wajib menyiapkan untuk pelaksanaan salat zuhur berjamaah seperti membentangkan sajadah, menyiapkan sound system ketika muazin mengumandangkan azan, merapikan sandal, dan sepatu jamaah serta menyiapkan kultum bagi kelas yang telah diberikan amanah sebelum melaksanakan salat zuhur secara berjamaah.

b. Mendirikan salat zuhur berjamaah
Salah satu upaya guru dalam membentuk moral siswa di sekolah adalah mendirikan salat zuhur berjamaah. Guru-guru di SMAN 2 Sungai Limau mempunyai kedisiplinan yang baik, disiplin dalam menjalani tugas sebagai guru serta sangat disiplin dalam melaksanakan salat zuhur berjamaah disekola. Guruguru dan murid telah terbiasa tepat waktu dalam melaksanakan salat zuhur berjamaah disekolah namun, sebagian siswa ada yang melalaikan ibadah salat tesebut.

c. Upaya Guru Menanamkan Moral Pada Siswa

Guru-guru SMAN 2 Sungai Limau memiliki karakter yang baik yang tercermin dari sikap guru-guru kepada siswa. Selain itu guru-guru dan seluruh stakeholder sekolah berupaya mencontohkan sikap dan perilaku yang baik. Misalnya ketika azan telah berkumandang di Mushola guru-guru langsung menuju mushola untuk melaksanakan salat zuhur secara berjamaah. Guru-guru SMAN 2 Sungai Limau selalu berupaya memberikan pembinaan moral yang optimal misalnya 10 menit suara azan akan dikumandangkan guru-guru dan seluruh stakeholder sekolah menuju ketempat area dimana terdapat keramaian di area sekolah misalnya kantin sekolah, lobi sekolah, area halaman belakang sekolah, dan warung-warung yang berada di luar area lingkungan sekolah. Tujuannya untuk mengajak siswa melaksanakan salat berjamaah.

d. Memberikan Nasehat Terhadap Siswa

Memberikan nasehat kepada siswa merupakan pendekatan yang 
sangat baik dalam menyentuh hati nurani siswa. Jika nasehat dari guru untuk mengingatkan siswa agar senantiasa dalam melaskanakan salat berjamaah diberikan secara berkelanjutan maka nasehat dari guru tersebut akan teringat dan siswa akan senantiasa dalam beribadah. Selain itu jika waktu salat telah masuk guru mengingatkan dan mengajak siswa agar menuju mushola untuk melaksanakan salat berjamaah. Adapun dengan memberikan nasehat secara berkelanjutan siswa merasa akan diperhatikan dalam melaksanakan salat secara berjamaah tepat waktu serta jika siswa lalai dalam melaksanakan maka guru-guru dan seluruh stakeholder sekolah akan selalu mengingatkan siswa agar siswa segera menuju mushola untuk melaksanakan salat zuhur secara berjamaah.

\section{Kegiatan Pendukung agar Siswa Melaksanakan salat zuhur berjamaah}

Rohis

Rohis adalah kerohanian islam sebagai bagian dari seksi ketaqwaan terhadap Tuhan Yang Maha Esa. Disamping itu definisi lain, rohis merupakan ekstrakurikuler berbasis keagamaan yang tujuan nya agar siswa lebih mendekatkan diri kepada Allah SWT. Tujuan didirikannya Rohis di SMAN 2 Sungai Limau adalah untuk menyadarkan siswa akan pentingnya nilai-nilai keagamaan, nilai-nilai religius religius dan masih banyak lagi hal yang berhubungan dengan nilainilai agama islam. Kegiatan Rohis di SMAN 2 Sungai Limau berupa mensyiarkan nilai-nilai agama kepada siswa, mengingatkan siswa akan pentingnya dalam melaksanakan ibadah salat berjamaah dan upaya yang Penulis lihat melalui kegiatan rohis untuk mengingatkan siswa akan pentingnya melaksanakan ibadah salat berjamaah sangat maksimal dengan memberikan contoh yang baik kepada siswa lainnya.

\section{Mabit (Malam Bina Iman dan Taqwa)}

Mabit merupakan program tambahan yang di beri pihak sekolah untuk memperlengkap ilmu agama dari siswa tersebut dan berguna dalam keseharian. Tujuannya agar semua siswa mengerti akan perlunya binaan iman dan ketaqwaan masing-masing murid. Murid di SMA N 2 Sungai Limau memberikan jadwal mabit ini pada hari jumat setelah jam pelajaran atau diluar jam pelajaran. Selain itu kegiatan inti dari program mabit ini adalah bagaimana guru dapat menyentuh hati siswa untuk senantiasa dalam melaksanakan ibadah salat dan guru menggunakan metode Muhasabah untuk menyentuh hati siswa agar siswa dapat berubah kearah yang lebih baik.

\section{Kultum pada hari jumat}

Melaksanakan kultum pada hari jumat merupakan kegiatan rutin yang di lakukan di SMAN 2 Sungai Limau. Tujuan diadakannya kultum pada hari jumat adalah memberikan pemahaman tentang ilmu agama kepada siswa dan memberikan ceramah ataupun nasehat kepada siswa. Kegiatan kultum tersebut adalah kegiatan rutin yang mana seluruh kelas bertanggung jawab apabila telah mendapatkan giliran untuk menyelenggarakan kegiatan kultum pada hari jumat serta memberikan ceramah yang berkaitan dengan keseharian siswa seperti melaksanakan ibadah salat berjamaah, sedekah, sabar dsb. 
Memaksimalkan kegiatan dari Forum Annisa

Forum Anisa adalah suatu forum atau pekumpulan wanitawanita yang tujuannya untuk mendalami agama islam dengan berbagai kegiatan yang positif dan dapat mendekatkan diri pada Allah SWT. Pada kegiatan forum Annisa ini setiap minggunya juga mengundang ustazah atau pemateri guna membahas materi terkait dengan ibadah seperti salat, keutamaan salat, zakat, sedekah serta ibadah yang sering kali dilakukan oleh siswa dalam kehidupan sehari-hari. Untuk mengundang pemateri atau ustazah, forum Annisa akan berkoordinasi dengan wakil kesiswaan guna untuk meminta izin agar agenda rutin di setiap minggun bisa terlaksana.

Memaksimalkan kegiatan dari forum ArRijal

Forum Ar-Rijal adalah suatu forum dsuatu forum atau perkumpulan laki-laki yang tujuannya untuk mendalami agama islam dengan berbagai kegiatan yang positif dan dapat mendekatkan diri pada Allah SWT. Pada kegiatan forum Ar-Rijal ini juga mengundang ustad atau pemateri guna untuk membahas terkait dengan ibadah seperti, keutamaan salat, zakat, sedekah serta ibadah yang sering kali dilakukan oleh siswa dalam kehidupan sehari-hari tidak hanya itu antara laki-laki dan perempuan sangat dijaga hijabnya. Untuk mengundang pemateri atau ustad forum Ar-Rijal akan berkoordinasi dengan wakil kesiswaan guna untuk meminta izin agar agenda rutin disetiap minggunya dapat terlaksana.

Pembinaan moral merupakan topik yang selalu hangat dibahas dalam dunia pendidikan. Banyak sekolah berlomba-lomba menjadi sekolah yang memiliki moral baik. Salah satu kunci penting mewujudkan pembinaan moral di rumah ialah melalui upaya orang tua dalam melakukan pembinaan moral terhadap anak secara maksimal. Hal ini dibuktikan dengan keterlibatan orang tua dalam melakukan aturan kedisiplinan dalam beribadah seperti salat berjemaah dan kegiatan maghrib mengaji dirumah.

Tugas orang tua dirumah
adalah memantau siswa secara
keseluruhan untuk melihat apa saja
aktivitas siswa. Ketika siswa lalai
dalam melaksanakan ibadah salat
maka adanya aturan disiplin dirumah
yang mengingatkan serta mengajak
secara langsung agar siswa bergegas
untuk menuju ke mushola. Upaya
orang tua sangat dibutuhkan untuk
membina moral siswa, karena dengan
pembinaan diharapkan siswa memiliki
perubahan kearah yang lebih baik.

\section{KESIMPULAN}

Berdasarkan pembahasan dan analisis di atas, peneliti dapat menyimpulkan bahwa upaya guru PPKn dan seluruh stakeholder sekolah dalam melakukan pembinaan moral telah maksimal. Hal ini dibuktikan dengan keterlibatan guru PPKn dan seluruh stakeholder sekolah dalam memberikan pembinaan terhadap siswa. Keberadaan aturan-turan yang tertera pada anggaran dasar dan anggaran rumah tanggal SMAN 2 Sungai Limau. Bagi semua guru-guru SMAN 2 Sungai Limau mengharuskan guru-guru mematuhi dan melaksankan aturan seperti kedisiplinanan, ibadah, karakter atau akhlak, moral yang baik, cara 
berpakaian. Guru-guru melaksanakan pembinaan secara berkelanjutan Karena pembinaan moral yang maksimal telah biasa dilakukan guruguru SMAN 2 Sungai Limau untuk senantiasa disiplin, rajin beribadah, berkarakter memiliki moral yang baik dalam segi beribadah yang baik.

\section{DAFTAR PUSTAKA}

Budiningsih, Asri. 2013. Pembelajaran Moral Berpijak pada Karakteristik Budayanya, Yokyakarta: PT Rineka Cipta

Bogdan dan Taylor. 1975. Metodologi Penelitian Kualitatif. Bandung: Remaja Karya

Mannan, (2017). Pembinaan Moral Untuk Memantapkan Watak Kewarganegaraan Siswa Sekolah Dasar Kelas Tinggi Jurnal Moral Kemasyarakatan, 2(2), 131-139. https:/ / doi.org/10.21067/jmk. v2i2.2256

Prof. Dr. Hamzah dan B. Uno, MPd. 2007.Profesi Kependidikan, Problema, Solusi, danReformasi Pendidikan di Indonesia, Jakarta: Perpustakaan Nasional. Sugiono. 2003, Metode Penelitian Pendidikan Pendekatan Kuantitatif, Kualitatif, dan R dan D. Bandung: CV Alfabeta

Sugiyono, 2013, Metodelogi Penelitian Kuantitatif, Kualitatif Dan R\&D. (Bandung: ALFABETA) 